\title{
Pentachlorophenol(PCP)-Tolerance of Bacteria Isolated from Soil Percolated with PCP
}

\author{
Kyo Sato \\ Institute for Agricultural Research, Tohoku University, \\ Katahira, Sendai 980, Japan
}

(Received November 25, 1986)

\begin{abstract}
Pentachlorophenol(PCP)-tolerance of bacterial strains isolated from percolated soil, where a bacterial flora was changed by applying PCP, was investigated. Pretreatment with PCP did not affect the tolerance of the strains. When they were cultured in media containing different concentrations of their estimated PCP-tolerance level, the strains differed in tolerance according to soil treatment. The tolerance was the highest in the strains isolated from the PCP-percolated soil, medium in those from the PCP and glycine-added soil and the lowest in those from the water-percolated soil. Taxonomical groups of the strains also seemed related with the difference in growth rate when PCP was applied to the tested medium at different concentrations. The nature of media also affected the tolerance of the strains.
\end{abstract}

\section{INTRODUCTION}

Pentachlorophenol (PCP) was used in a large quantity as a herbicide for rice paddy in Japan, but since 1971 the use has been restricted because of its high toxicity to fish in rivers and ponds. ${ }^{1)}$ Today PCP is mainly used as a wood preservative and partly for upland crops, and its persistence in the natural environment including soil has been discussed.

There are many studies on microbial degradation of PCP in soil ${ }^{1-6)}$ but works on the effect of the pesticide on soil microflora, especially on soil bacterial flora are relatively few.

The author reported that a bacterial flora in water-logged or percolated soil changed when PCP was applied to the soil. ${ }^{-9)}$ Some stress factors in the natural environment, such as high temperature, extreme $\mathrm{pH}$ and chemical pollution, often decrease species diversity and population, and only the species endurable to such stresses can survive. ${ }^{10)}$ The purpose of the present work was to investigate the difference in PCP-tolerance among bacterial strains isolated from percolated soil treated or untreated with PCP.

\section{MATERIALS AND METHODS}

\section{Isolation of Bacterial Strains}

Strains used in the present study were isolated on the 5 th day of percolation from percolated soil treated differently. ${ }^{9)}$ Strains isolated from the water-percolated soil untreated with PCP were termed W-strains, those from the soil treated with PCP P-strains, and those from the glycine-percolated soil untreated with PCP G-strains. The strains were also isolated on the 5th and 15th days from the glycine-percolated soil treated with PCP and termed GP5- and GP15-strains, respectively. ${ }^{9)}$ Main characteristics of taxonomically assorted bacterial groups of the isolated strains are listed in Table 1, followed by a scheme described previously. ${ }^{9}$

A soil used for percolation was an alluvial garden soil, $\mathrm{pH} 6.39\left(\mathrm{H}_{2} \mathrm{O}\right)$ and organic matter $6.60 \%$ (as ignition loss). ${ }^{8)}$

\section{Stock Cultivation}

All strains were maintained at $5{ }^{\circ} \mathrm{C}$ on an agar slant of nutrient broth containing no PCP until investigated. The nutrient broth consist- 
Table 1 Main characteristics of bacterial groups. ${ }^{9)}$

\begin{tabular}{|c|c|}
\hline $\begin{array}{l}\text { Bacterial } \\
\text { groups }^{\mathrm{a}} \text { ) }\end{array}$ & Characteristics \\
\hline I & $\begin{array}{l}\text { Non-motile, yellow- or orange-pigmented, } \\
\text { Kovacs' oxidase positive or negative }\end{array}$ \\
\hline II & $\begin{array}{l}\text { Non-motile, non-pigmented, Kovacs' oxi- } \\
\text { dase negative }\end{array}$ \\
\hline III & $\begin{array}{l}\text { Motile with peritrichous flagella, Kovacs' } \\
\text { oxidase negative, oxidative in Hugh \& } \\
\text { Leifson's test }\end{array}$ \\
\hline IV & $\begin{array}{l}\text { Motile with peritrichous flagella, Kovacs' } \\
\text { oxidase negative, fermentative in Hugh } \\
\text { \& Leifson's test }\end{array}$ \\
\hline $\mathrm{V}$ & $\begin{array}{l}\text { Motile with polar flagella, Kovacs' oxi- } \\
\text { dase positive, fermentative in Hugh \& } \\
\text { Leifson's test }\end{array}$ \\
\hline VI & $\begin{array}{l}\text { Motile with polar flagella, Kovacs' oxi- } \\
\text { dase positive, neither oxidative nor } \\
\text { fermentative in Hugh \& Leifson's test }\end{array}$ \\
\hline VII & $\begin{array}{l}\text { Motile with polar flagella, Kovacs' oxi- } \\
\text { dase positive, oxidative in Hugh \& } \\
\text { Leifson's test }\end{array}$ \\
\hline VIIa & $\begin{array}{l}\text { Gelatin-liquefaction positive, nitrate- } \\
\text { reduction negative }\end{array}$ \\
\hline $\mathrm{VIIb}$ & $\begin{array}{l}\text { Gelatin-liquefaction positive, nitrate- } \\
\text { reduction positive }\end{array}$ \\
\hline VIIc & $\begin{array}{l}\text { Gelatin-liquefaction negative, nitrate- } \\
\text { reduction positive, alkaline reaction of } \\
\text { BCP milk }\end{array}$ \\
\hline VIIc $^{\prime}$ & $\begin{array}{l}\text { Gelatin-liquefaction negative, nitrate- } \\
\text { reduction positive, acid reaction of BCP } \\
\text { milk }\end{array}$ \\
\hline VIId & $\begin{array}{l}\text { Gelatin-liquefaction negative, nitrate- } \\
\text { reduction negative, alkaline reaction of } \\
\text { BCP milk }\end{array}$ \\
\hline VIId' $^{\prime}$ & $\begin{array}{l}\text { Gelatin-liquefaction negative, nitrate- } \\
\text { reduction negative, acid reaction of } \\
\text { BCP milk }\end{array}$ \\
\hline $\begin{array}{l}\text { Gram- } \\
\text { positive } \\
\text { bacteria }\end{array}$ & $\begin{array}{l}\text { Non-spore forming rod-shaped cells, no } \\
\text { flagellated or peritrichous flagella, pig- } \\
\text { mented or non-pigmented, catalase } \\
\text { positive }\end{array}$ \\
\hline
\end{tabular}

a) All bacterial strains included from group I to group VIId' are gram-negative, rod-shaped cells, catalase positive, negative in indol production, methyl red and Voges-Proskauer tests, and not heat-resistant. Genera subsumed in each group: I, Flavobacterium; II, Acinetobacter; III, Achromobacter; IV, not subsumed; V, not subsumed; VI, Pseudomonas; VII, Pseudomonas groups other than that of group VI; VIIa, VIIb, VIIc, VIIc', VIId and VIId' denote different types of Pseudomonas within group VII.

ed of $10.0 \mathrm{~g}$ meat extract (Kyokuto Chemical Industries Ltd., Tokyo), $10.0 \mathrm{~g}$ polypeptone (Wako Pure Chemical Industries Ltd., Tokyo) and $5.0 \mathrm{~g} \mathrm{NaCl}$ in $1 l$ distilled water, and $13.0 \mathrm{~g}$ agar was added in the case of an agar medium. The medium was adjusted to $\mathrm{pH} 7.0$ with $1 \mathrm{~N}$ $\mathrm{NaOH}$ or $1 \mathrm{~N} \mathrm{HCl}$. All investigations were carried out at $30^{\circ} \mathrm{C}$, unless otherwise stated.

\section{Growth in Different Media}

Cells were suspended in $10 \mathrm{ml}$ of $0.5 \%$ $\mathrm{NaCl}$ solution after grown on the nutrient broth agar for $24 \mathrm{hr}$. Three aliquots of the suspended cells were inoculated into the nutrient broth containing $0,10,50$ or $100 \mathrm{ppm}$ PCP. They were also inoculated into three different media, $\mathrm{A}, \mathrm{B}$ and $\mathrm{C}$ which also contained $0,10,50$ or $100 \mathrm{ppm}$ PCP. The growth of the bacteria was confirmed by visible turbidity of the cultures after 5 days of incubation. Medium A comprised $2.0 \mathrm{~g}$ glucose and $0.5 \mathrm{~g} \mathrm{NH}_{4} \mathrm{NO}_{3}$ and medium $\mathrm{B}, 2.0 \mathrm{~g}$ casein hydrolysates, in $1 l$ of basal salt solution. The basal salt solution comprised $(\mathrm{g} / l): \mathrm{KH}_{2} \mathrm{PO}_{4}$, $0.2 ; \mathrm{K}_{2} \mathrm{HPO}_{4}, 0.5 ; \mathrm{MgSO}_{4} \cdot 7 \mathrm{H}_{2} \mathrm{O}, 0.2 ; \mathrm{NaCl}$, $0.2 ; \mathrm{CaCl}_{2} \cdot 2 \mathrm{H}_{2} \mathrm{O}, 0.5 ; \mathrm{FeSO}_{4} \cdot 7 \mathrm{H}_{2} \mathrm{O}, 0.025$; $\mathrm{Na}_{2} \mathrm{MoO}_{4}, 0.005 ; \mathrm{MnSO}_{4}, 0.0005 ; \mathrm{Na}_{2} \mathrm{WO}_{4}$, 0.0005 . The medium $\mathrm{C}$ comprised $(\mathrm{g} / \mathrm{l})$ : egg albumin, 0.25 ; glucose, $1.0 ; \mathrm{K}_{2} \mathrm{HPO}_{4}, 0.5$; $\mathrm{MgSO}_{4} \cdot 7 \mathrm{H}_{2} \mathrm{O}, \quad 0.2 ; \quad \mathrm{Fe}_{2}\left(\mathrm{SO}_{4}\right)_{3} \cdot n \mathrm{H}_{2} \mathrm{O}$, trace; yeast extract, 0.5 . All the media were adjusted to $\mathrm{pH} 7.0$ with $1 \mathrm{~N} \mathrm{NaOH}$ or $1 \mathrm{~N} \mathrm{HCl}$.

\section{Training of Bacteria with PCP and Mea- surement of Growth Rates}

Figure 1 depicts a general procedure for testing the effect of PCP on growth rates of the strains: For training the bacterial cells against PCP under non-growing conditions, the cells precultured on the nutrient broth agar for 18 hr were inoculated into mineral salt solution with or without $100 \mathrm{ppm}$ PCP and incubated for $3 \mathrm{hr}$. Two aliquots of the incubated cells were inoculated into the nutrient broth with or without $100 \mathrm{ppm}$ PCP. The components of the mineral salt solution were the same as those of media A and B.

For selecting the bacterial cells tolerant of PCP under growing conditions, $1 \mathrm{ml}$ aliquots of the cultures grown in the nutrient broth for $18 \mathrm{hr}$ were inoculated into $10 \mathrm{ml}$ portions of nutrient broth containing different concentrations of $\operatorname{PCP}(0,50$ and $100 \mathrm{ppm})$. After culturing the inoculated media for $24 \mathrm{hr}$, three 


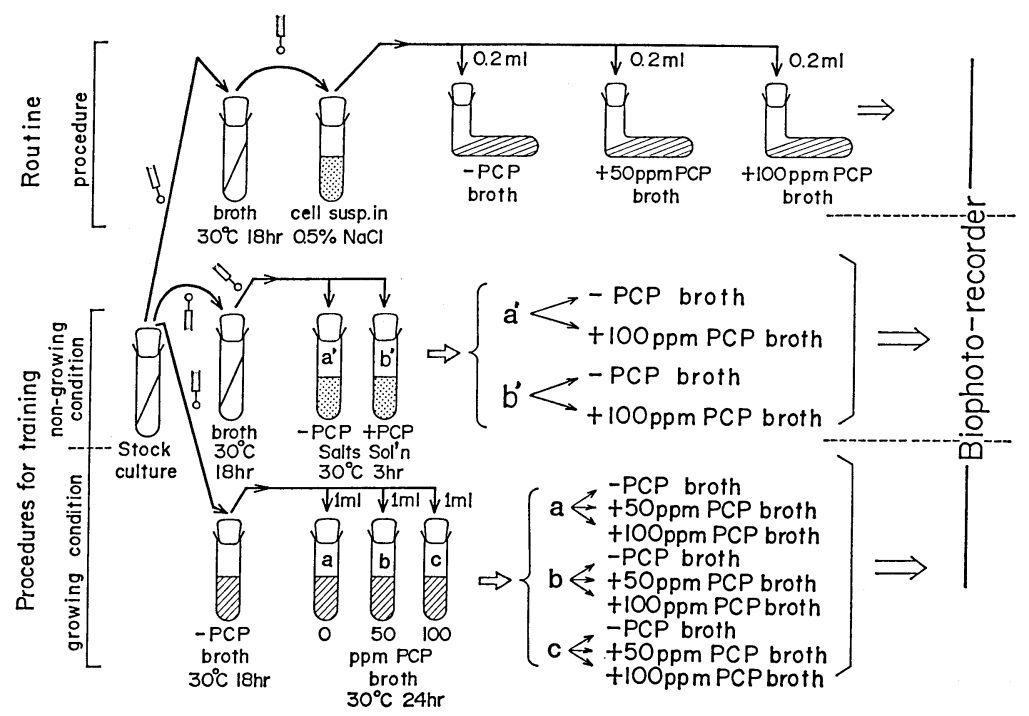

Fig. 1 A schematic illustration of experimental procedures.

aliquots of the respective cultures were inoculated into the nutrient broth containing PCP $(0,50$ and $100 \mathrm{ppm})$ to measure their growth rates.

All of the cultures were incubated with shaking and their growth was followed turbidmetrically at $660 \mathrm{~nm}$ by a biophotorecorder (TN-124D, Toyo Kagaku Sangyo Co. Ltd., Tokyo). The growth rate was measured on the slope of the logarithmic growth phase of a growth curve.

To test the effect, the cells cultured on the nutrient broth agar were suspended in $10 \mathrm{ml}$ of $0.5 \% \mathrm{NaCl}$ solution, and $0.2 \mathrm{ml}$ aliquots of the cell suspension were inoculated into the nutrient broth containing different concentrations of PCP $(0,50$ and $100 \mathrm{ppm})$, and incubated with shaking to measure the growth rate as described.

\section{Evaluation of Tolerance for PCP}

PCP-tolerance was evaluated based on the relative growth rate of bacteria. It was calculated from $\tan \theta$ of the slope of the logarithmic growth phase of the growth curve (Fig. 2) as follows:

Relative growth rate at $100 \mathrm{ppm} \mathrm{PCP}=$ $(\tan \theta c / \tan \theta a) \times 100$, and those at $50 \mathrm{ppm}$ $\mathrm{PCP}=(\tan \theta b / \tan \theta a) \times 100$, respectively, where $\theta a$ denotes the angle of inclination of the

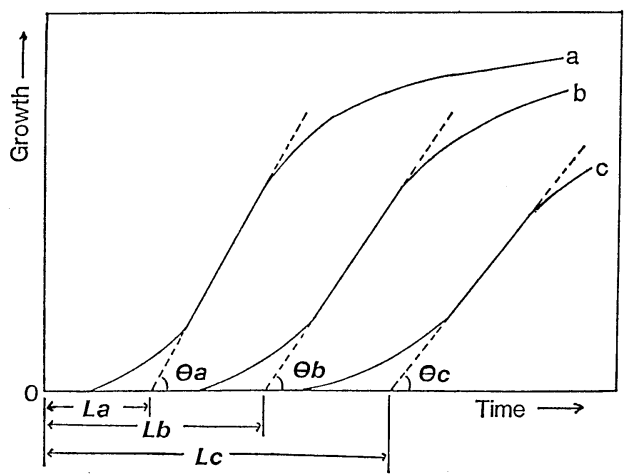

Fig. 2 Growth curves of a bacterial strain in the presence of different concentrations of PCP.

a, without PCP; b, $50 \mathrm{ppm} \mathrm{PCP;} \mathrm{c,} 100 \mathrm{ppm}$ PCP.

logarithmic growth phase at $0 \mathrm{ppm} \mathrm{PCP}, \theta b$ at $50 \mathrm{ppm} \mathrm{PCP}$, and $\theta c$ at $100 \mathrm{ppm} \mathrm{PCP.}$ Duration of the lag phase to start the growth was arbitrarily taken as period $L a, L b$ or $L c$ of the respective cultures as shown in Fig. 2.

\section{RESULTS AND DISCUSSION}

\section{Effect of Preincubation on PCP-tolerance}

To examine whether or not bacteria were trained for PCP-tolerance, the effects of preincubation with PCP were tested on strains W-12, G-11, P-1, GP5-7 and GP15-1 which 


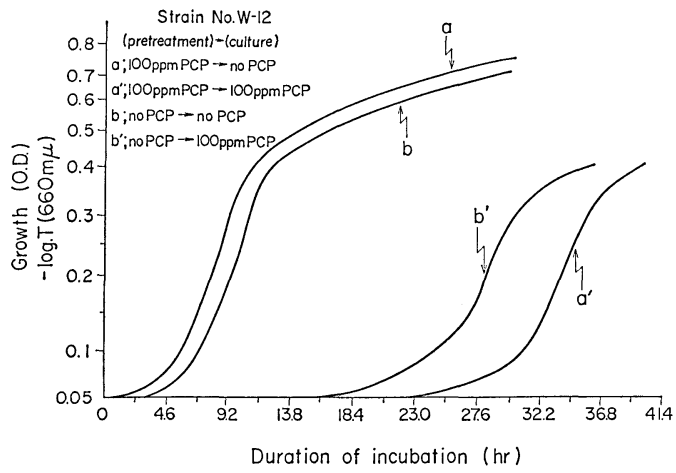

Fig. 3 Effect of pretreatment under non-growing conditions.

had been arbitrarily selected as representatives of the respective strains isolated from different plots of percolated soil. Figures 3 and 4 indicate that preincubation did not affect $\mathrm{PCP}$-tolerance of strain W-12. PCP treatment did not affect the growth rate of the strain, although the growth rates were somewhat lower in the medium treated with PCP than in the medium untreated with PCP (pretreatment under nongrowing conditions) (Fig. 3). The respective growth rates in the medium containing different concentrations of PCP were similar irrespective of preculturing of bacteria in the medium of different PCP contents (pretreatment under growing conditions) (Fig. 4). The bacterial cells showed the same growth curves and grew most rapidly in the medium without PCP in spite of preculturing in the medium of different PCP contents (curve-1s in Fig. 4 a, $\mathrm{b}$ and $\mathrm{c}$ ). The cells also showed the similar and lowest growth rates in the medium containing $100 \mathrm{ppm}$ PCP irrespective of preculturing in the medium of different PCP contents (curve$3 \mathrm{~s}$ in Fig. $4 \mathrm{a}, \mathrm{b}$ and $\mathrm{c}$ ). This means that the cells tolerant of PCP were not selected by preculturing in the presence of $\mathrm{PCP}$, and that the increased applications of PCP to the growth medium inhibited the growth of the bacterial cells.

Similar results were also observed in all other strains tested, leading to the conclusion that PCP-tolerance is not affected by preculturing with PCP.

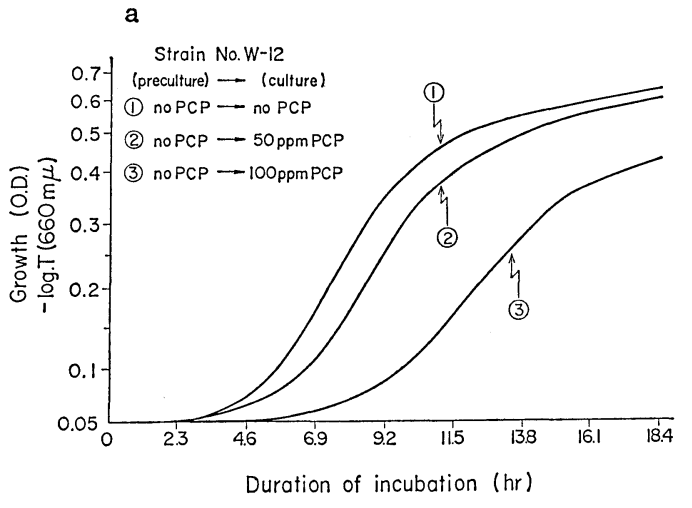

b
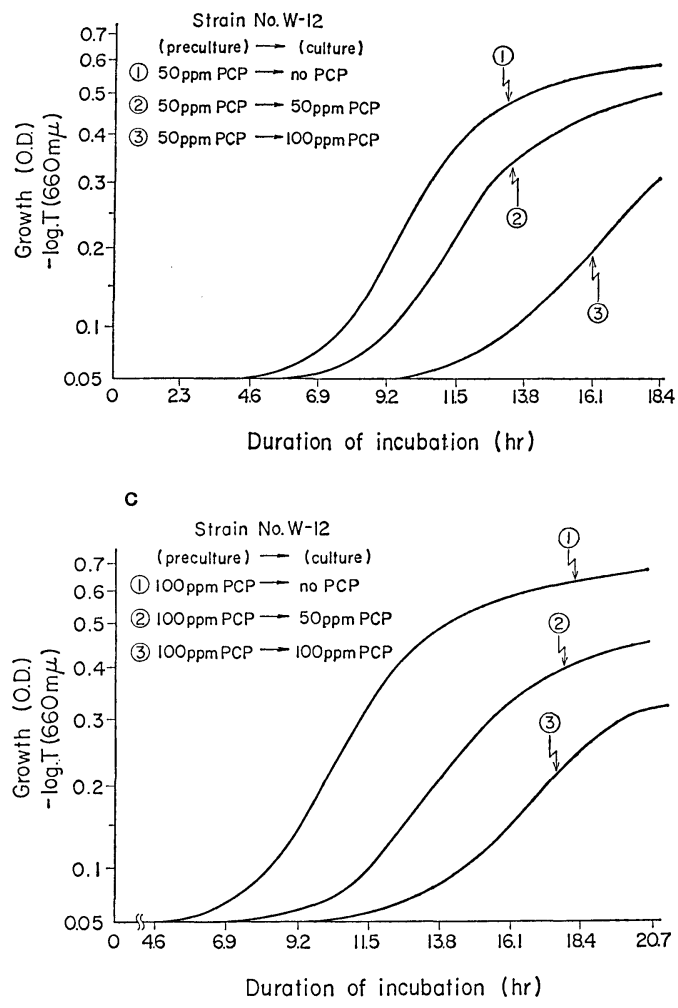

Fig. 4 Effect of pretreatment under growing conditions.

a, precultured without $\mathrm{PCP}$; b, with $50 \mathrm{ppm}$ PCP; c, 100 ppm PCP.

\section{Growth in Nutrient Broth Containing Differ- ent Concentrations of $P C P$}

In general, PCP-resistance was related to a bacterial group the respective strain belonged to (Table 2). Bacteria belonging to a gram- 
Table 2 Effect of PCP concentrations on the growth of strains.

\begin{tabular}{|c|c|c|c|c|c|}
\hline \multirow{2}{*}{ Bacterial groups } & \multirow{2}{*}{ Strain No. } & \multicolumn{4}{|c|}{ Concentration of PCP (ppm) } \\
\hline & & 0 & 10 & 50 & 100 \\
\hline \multirow{2}{*}{ I } & G-3 & + & + & + & \\
\hline & G-15 & + & + & & \\
\hline \multirow{5}{*}{ II } & $\mathrm{W}-1$ & + & + & + & + \\
\hline & W-2 & + & + & + & \\
\hline & W-9 & + & + & + & \\
\hline & W-14 & + & + & + & \\
\hline & $\mathrm{W}-15$ & + & + & + & \\
\hline \multirow{4}{*}{ III } & GP15-1 & + & + & + & + \\
\hline & GP15-9 & + & + & + & + \\
\hline & GP15-24 & + & + & + & + \\
\hline & GP15-25 & + & + & + & + \\
\hline IV & GP5-7 & + & + & + & + \\
\hline \multirow{5}{*}{$\mathrm{V}$} & $\mathrm{W}-3$ & + & \pm & & \\
\hline & G-8 & + & + & & \\
\hline & G-16 & + & + & & \\
\hline & G-21 & + & + & + & \\
\hline & GP15-15 & + & + & & \\
\hline \multirow{5}{*}{ VI } & $\mathrm{P}-1$ & + & + & + & + \\
\hline & P-4 & + & + & + & + \\
\hline & P-5 & + & + & + & + \\
\hline & P-8 & + & + & + & + \\
\hline & P-15 & + & + & + & + \\
\hline VIIa & $\mathrm{W}-7$ & + & + & + & \\
\hline VIIb & GP5-20 & + & + & + & + \\
\hline \multirow{17}{*}{ VIIc } & W-5 & + & + & + & + \\
\hline & $\mathrm{W}-12$ & + & + & + & + \\
\hline & G-1 & + & + & + & + \\
\hline & G-2 & + & + & + & + \\
\hline & G-5 & + & + & + & + \\
\hline & G-6 & + & + & + & + \\
\hline & G-7 & + & + & + & + \\
\hline & G-9 & + & + & + & + \\
\hline & G-12 & + & + & + & + \\
\hline & G-13 & + & + & + & + \\
\hline & G-14 & + & + & + & + \\
\hline & G-17 & + & + & + & \\
\hline & G-19 & + & + & + & + \\
\hline & G-22 & + & + & + & + \\
\hline & $\begin{array}{l}\text { G-24 } \\
\text { G-25 }\end{array}$ & $\begin{array}{l}+ \\
+\end{array}$ & $\begin{array}{l}+ \\
+\end{array}$ & $\begin{array}{l}+ \\
+\end{array}$ & $\begin{array}{l}+ \\
+\end{array}$ \\
\hline & G-28 & + & + & + & + \\
\hline & GP15-30 & + & + & + & + \\
\hline \multirow{2}{*}{ VIIc' $^{\prime}$} & $\mathrm{W}-13$ & + & + & + & + \\
\hline & P-13 & + & + & + & + \\
\hline
\end{tabular}


Table 2 (Continued)

\begin{tabular}{|c|c|c|c|c|c|}
\hline \multirow{2}{*}{ Bacterial groups } & \multirow{2}{*}{ Strain No. } & \multicolumn{4}{|c|}{ Concentration of PCP (ppm) } \\
\hline & & 0 & 10 & 50 & 100 \\
\hline \multirow{12}{*}{ VIId } & $\mathrm{W}-3$ & + & + & & \\
\hline & $\mathrm{W}-11$ & + & + & + & + \\
\hline & G-11 & + & + & + & + \\
\hline & G-20 & + & + & & \\
\hline & G-23 & + & + & & \\
\hline & GP5-6 & + & + & + & + \\
\hline & GP5-10 & + & + & + & \\
\hline & GP5-15 & + & + & + & \\
\hline & GP5-16 & + & + & + & \\
\hline & GP5-17 & + & + & + & \\
\hline & GP5-24 & + & + & + & \\
\hline & GP5-28 & + & + & + & + \\
\hline \multirow{5}{*}{ VIId $^{\prime}$} & G-10 & + & + & & \\
\hline & G-18 & + & + & & \\
\hline & G-26 & + & + & & \\
\hline & G-27 & + & + & & \\
\hline & G-29 & + & + & & \\
\hline \multirow{4}{*}{ Gram-positive } & $\mathrm{W}-6$ & + & & & \\
\hline & GP5-4 & + & & & \\
\hline & GP15-3 & + & & & \\
\hline & GP15-5 & + & + & + & + \\
\hline
\end{tabular}

+ , luxuriant growth; \pm , scanty growth.

positive group did not grow in the presence of 10 ppm PCP except for one strain, GP15-5 which grew at $100 \mathrm{ppm}$ PCP. Strains belonging to groups III, IV, VI, VIIb, VIIc and VIIc' $^{\prime}$ grew at $100 \mathrm{ppm}$ PCP except for one strain, G-17. On the other hand, most strains of groups II, VIIa and VIId did not grow at $100 \mathrm{ppm}$ but grew at $50 \mathrm{ppm}$ PCP. Exceptions were strains W-1, W-11, G-11, GP5-6 and GP5-28 which grew at $100 \mathrm{ppm}$ PCP, and strains W-3, G-20 and G-23 which did not grow at $50 \mathrm{ppm}$ PCP. Strains of groups $\mathrm{V}$ and VIIc' $^{\prime}$ did not grow at $50 \mathrm{ppm}$ but grew at 10 ppm PCP except for one strain, G-21. Two strains belonged to group I: one showed resistance to $50 \mathrm{ppm} \mathrm{PCP}$ and the other did not tolerate the same concentration.

3. Growth Rates and Growth Lag in Nutrient Broth Containing Different Concentrations of PCP

Relative growth rates of the strains in the medium clearly varied with bacterial group
(Fig. 5). Generally, group VI comprising Pstrains showed the highest growth rate with its lowest being $65 \%$ at $100 \mathrm{ppm}$, while groups $\mathrm{V}$, VIId' and gram-positive bacteria showed the lowest growth rate of $0 \%$ at both 50 and $100 \mathrm{ppm}$ PCP, except for two strains, G-21 and GP15-5, whose growth rates were $80 \%$ at 50 ppm and $85 \%$ at $100 \mathrm{ppm}$, respectively. Growth rates were lower in group II strains than in groups III and VIIc: the rates of most strains in the former group were $0 \%$ at $100 \mathrm{ppm}$ and between $55 \%$ and $80 \%$ at 50 ppm. Most strains of group VIId did not grow at $100 \mathrm{ppm}$, but many of them showed high growth rates $(70-100 \%)$ at $50 \mathrm{ppm}$. Group VIId may differ in growth pattern from the other groups.

The studies on the level of PCP-resistance of various kinds of named bacteria showed that gram-negative bacteria were generally more resistant to PCP than gram-positive bacteria. ${ }^{11)}$ The results in Table 2 coincide with the previous findings. ${ }^{11)}$ Moreover, it was confirmed 


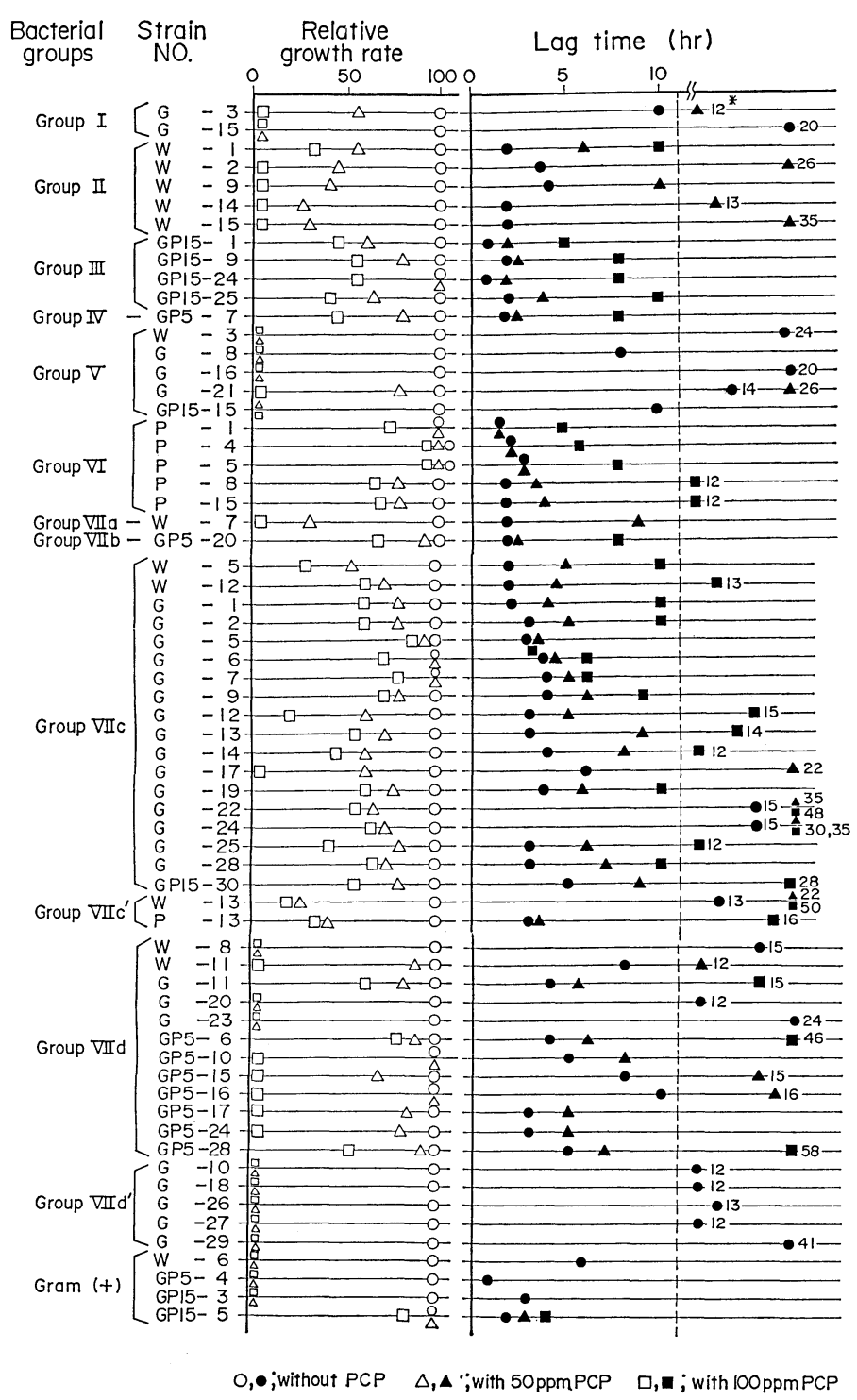

Fig. 5 Relative growth rate and lag of growth.

* Numbers denote time of lag in hr.

based on the growth rates that PCP-resistance differs depending on the bacterial groups in which the strains of gram-negative bacteria are taxonomically assorted. Difference in resistance among the respective groups of gram-negative bacteria could not be determined based on the growth characteristics shown in Table 2, but, comparison of the growth rates clearly shows the difference in resistance among the groups. Therefore, it is possible to postulate that the growth rate is an effective factor to determine the tolerance for PCP in connection with the taxonomic position.

All the strains of group VI were isolated from the soil percolated with PCP without adding any nutrient. All the strains of groups III, IV and VIIb isolated from the glycinepercolated soil treated with PCP also showed comparatively high growth rates in the presence of PCP, but their growth rates were 
lower than those of group VI. Most strains of group VIIc isolated from the glycine-percolated soil had comparatively high growth rates, while most of the strains isolated from the glycine-percolated soil and belonged to other groups did not show high growth rates. The GP-strains of group VIId showed higher growth rates at $50 \mathrm{ppm}$ PCP compared with $\mathrm{G}$ - and $\mathrm{W}$-strains of the same group. The Wstrains in group II and other groups had low growth rates in the presence of PCP.

Above findings suggest that PCP rigidly selects bacteria highly tolerant of PCP in soil, and that the presence of glycine as a nutrient neutralizes the impact of PCP as a stimulant to select the bacteria highly tolerant of the pesticide. Glycine itself may also act diversely to select pesticide-tolerant bacteria in soil. Bacteria tolerant of pesticides to some extent can be established by using common microbial nutrients in soil. Pesticide-tolerance does not develop without nutrient.

Duration of the lag period before the initiation of growth was generally longer in the medium containing $100 \mathrm{ppm}$ PCP than the one containing lower concentrations of PCP. The higher the growth rate, the shorter the lag of growth (Fig. 5).

\section{Effect of Nature of Growth Media on PCP- Tolerance}

PCP-tolerance was affected by the nature of media (Table 3). In general, the more complex the ingredients of media, the more resistant the strains to PCP. The growth of some strains was also affected by the nature of media even at $10 \mathrm{ppm}$ PCP; strains W-1, P-1, P-4, W-12 and $\mathrm{G}-20$ did not grow in medium $\mathrm{A}$ but did

Table 3 Effect of constituents of media on the growth of strains at different PCP concentrations.

\begin{tabular}{|c|c|c|c|c|c|c|c|c|c|c|c|c|c|}
\hline \multirow{3}{*}{ Bacterial groups } & \multirow{3}{*}{ Strain No. } & \multicolumn{12}{|c|}{ Concentration of PCP (ppm) } \\
\hline & & \multicolumn{3}{|c|}{0} & \multicolumn{3}{|c|}{10} & \multicolumn{3}{|c|}{50} & \multicolumn{3}{|c|}{100} \\
\hline & & $A^{a)}$ & $B^{a)}$ & $C^{a)}$ & $\mathrm{A}$ & $\mathrm{B}$ & $\mathrm{C}$ & A & B & $\mathrm{C}$ & A & $\mathrm{B}$ & $\mathrm{C}$ \\
\hline \multirow{2}{*}{ I } & G-3 & + & + & + & + & + & + & + & + & + & - & - & - \\
\hline & G-15 & + & + & + & + & + & + & - & - & - & - & - & - \\
\hline \multirow{5}{*}{ II } & W-1 & + & + & + & - & + & + & - & - & + & - & - & + \\
\hline & W-2 & - & + & + & - & + & + & - & + & + & - & - & - \\
\hline & W-9 & - & + & + & - & \pm & + & - & - & + & - & - & - \\
\hline & $\mathrm{W}-14$ & + & + & + & \pm & + & + & - & + & + & - & - & - \\
\hline & $\mathrm{W}-15$ & - & + & + & - & + & + & - & - & + & - & - & - \\
\hline \multirow{4}{*}{ III } & GP15-1 & + & + & + & + & + & + & + & + & + & - & - & + \\
\hline & GP15-9 & + & + & + & + & + & + & + & + & + & \pm & + & + \\
\hline & GP15-24 & + & + & + & + & + & + & - & + & + & - & - & + \\
\hline & GP15-25 & + & + & + & + & + & + & + & + & + & - & + & + \\
\hline IV & GP5-7 & \pm & + & + & \pm & + & + & - & + & + & - & - & - \\
\hline \multirow{5}{*}{$\mathrm{V}$} & W-3 & - & + & + & - & \pm & + & - & - & - & - & - & - \\
\hline & G-8 & - & + & + & - & + & + & - & - & - & - & - & - \\
\hline & G-16 & - & + & + & - & + & + & - & - & - & - & - & - \\
\hline & G-21 & - & + & + & - & + & + & - & - & + & - & - & - \\
\hline & GP15-15 & + & + & + & + & + & + & - & - & - & - & - & - \\
\hline \multirow{5}{*}{ VI } & P-1 & + & + & + & - & + & + & - & + & + & - & - & + \\
\hline & P-4 & + & + & + & - & + & + & - & - & + & - & - & + \\
\hline & P-5 & \pm & + & + & \pm & + & + & - & + & + & - & - & + \\
\hline & P-8 & - & + & + & - & + & + & - & - & + & - & - & + \\
\hline & P-15 & - & + & + & - & + & + & - & + & + & - & - & + \\
\hline
\end{tabular}


Table 3 (Continued)

\begin{tabular}{|c|c|c|c|c|c|c|c|c|c|c|c|c|c|}
\hline \multirow{3}{*}{ Bacterial groups } & \multirow{3}{*}{ Strain No. } & \multicolumn{12}{|c|}{ Concentration of PCP (ppm) } \\
\hline & & \multicolumn{3}{|c|}{0} & \multicolumn{3}{|c|}{10} & \multicolumn{3}{|c|}{50} & \multicolumn{3}{|c|}{100} \\
\hline & & $A^{a)}$ & $B^{a)}$ & $C^{a)}$ & A & B & $\mathrm{C}$ & $\mathrm{A}$ & B & $\mathrm{C}$ & $\mathrm{A}$ & $\mathrm{B}$ & $\mathrm{C}$ \\
\hline VIIa & $\mathrm{W}-7$ & + & + & + & + & + & + & - & - & + & - & - & - \\
\hline VIIb & GP5-20 & - & \pm & + & - & \pm & + & - & \pm & + & - & - & + \\
\hline \multirow{18}{*}{ VIIc } & W-5 & - & + & + & - & + & + & - & + & + & - & - & + \\
\hline & $\mathrm{W}-12$ & + & + & + & - & - & + & - & - & + & - & - & + \\
\hline & G-1 & + & + & + & + & + & + & + & + & + & - & + & + \\
\hline & G-2 & + & + & + & + & + & + & + & + & + & - & - & + \\
\hline & G-5 & + & + & + & + & + & + & + & + & + & - & - & + \\
\hline & G-6 & - & + & + & - & + & + & - & - & + & - & - & + \\
\hline & G-7 & + & + & + & + & + & + & + & + & + & - & + & + \\
\hline & G-9 & + & + & + & + & + & + & + & + & + & - & + & + \\
\hline & G-12 & - & + & + & - & + & + & - & + & + & - & + & + \\
\hline & G-13 & + & + & + & + & + & + & + & + & + & - & + & + \\
\hline & G-14 & + & + & + & + & + & + & + & + & + & - & + & + \\
\hline & G-17 & + & + & + & + & + & + & + & + & + & - & - & - \\
\hline & G-19 & + & + & + & + & + & + & - & + & + & - & + & + \\
\hline & $\mathrm{G}-22$ & - & + & + & - & \pm & + & - & + & + & - & - & + \\
\hline & G-24 & - & + & + & - & + & + & - & + & + & - & - & + \\
\hline & G-25 & + & + & + & + & + & + & + & + & + & + & + & + \\
\hline & G-28 & + & + & + & + & + & + & \pm & \pm & + & - & - & + \\
\hline & GP15-30 & + & + & + & + & + & + & + & + & + & - & - & + \\
\hline \multirow{2}{*}{$\mathrm{VIIc}^{\prime}$} & W-13 & - & + & + & - & + & + & - & - & + & - & - & + \\
\hline & $\mathrm{P}-13$ & \pm & + & + & \pm & + & + & - & - & + & - & - & + \\
\hline \multirow{12}{*}{ VIId } & W-8 & + & + & + & + & + & + & - & - & - & - & - & - \\
\hline & $\mathrm{W}-11$ & - & - & + & - & - & + & - & - & + & - & - & + \\
\hline & G-11 & + & + & + & + & + & + & - & + & + & - & + & + \\
\hline & $\mathrm{G}-20$ & - & + & + & + & + & + & - & - & - & - & - & - \\
\hline & $\mathrm{G}-23$ & - & + & + & - & + & + & - & - & - & - & - & - \\
\hline & GP5-6 & - & + & + & - & + & + & - & - & + & - & - & + \\
\hline & GP5-10 & - & + & + & - & + & + & - & - & + & - & - & + \\
\hline & GP5-15 & + & + & + & + & + & + & + & + & + & - & - & - \\
\hline & GP5-16 & - & + & + & - & + & + & - & - & + & - & - & - \\
\hline & GP5-17 & \pm & \pm & + & \pm & \pm & + & - & - & + & - & - & - \\
\hline & GP5-24 & + & + & + & $\bar{t}$ & $\overline{+}$ & + & - & + & + & - & - & - \\
\hline & GP5-28 & - & + & + & - & + & + & - & + & + & - & - & + \\
\hline \multirow{5}{*}{ VIId' } & G-10 & + & + & + & + & + & + & - & - & - & - & - & - \\
\hline & G-18 & + & + & + & + & + & + & - & - & - & - & - & - \\
\hline & G-26 & + & + & + & + & + & + & - & - & - & - & - & - \\
\hline & G-27 & + & + & + & + & + & + & - & - & - & - & - & - \\
\hline & G-29 & + & + & + & + & + & + & - & - & - & - & - & - \\
\hline \multirow{4}{*}{ Gram-positive } & W-6 & - & - & + & - & - & - & - & - & - & - & - & - \\
\hline & GP5-4 & + & + & + & - & - & - & - & - & - & - & - & - \\
\hline & GP15-3 & + & + & + & - & - & - & - & - & - & - & - & - \\
\hline & GP15-5 & + & + & + & + & + & + & - & + & + & - & - & + \\
\hline
\end{tabular}

a) A, B and C, media.

+ , luxuriant growth; \pm , scanty growth; - , no growth. 
in media $\mathrm{B}$ and $\mathrm{C}$ at $10 \mathrm{ppm} \mathrm{PCP}$. The strains which grew in media $\mathrm{B}$ and $\mathrm{C}$ but did not in medium $\mathrm{A}$ in the presence of $50 \mathrm{ppm} \mathrm{PCP}$ increased in number. Of the strains which grew in medium $\mathrm{C}$ at $100 \mathrm{ppm} \mathrm{PCP}$, only 11 strains grew in medium $\mathrm{B}$ at the same $\mathrm{PCP}$ concentration.

PCP has been known as an uncoupler of oxidative phosphorylation in respiration. ${ }^{12)}$ Bacteria have to synthesize cell materials from glucose and an inorganic nitrogen compound or amino acids in medium $\mathrm{A}$ or $\mathrm{B}$ and from albumin (a kind of protein) in medium C, respectively. Protein synthesis from low molecular weight compounds requires more energy than from high molecular weight compounds. If bacteria can not grow due to the inability to synthesize cell materials in medium $\mathrm{A}$ or $\mathrm{B}$ in the presence of $\mathrm{PCP}$, the reason is probably that enough energy is not generated to support the synthesis because of uncoupling in oxidative phosphorylation.

A decrease in population of anaerobic bacteria when PCP was supplied to water-logged soil may be another cause of inhibition. ${ }^{7)} \mathrm{Al}-$ though real cause of difference in growth inhibition among the media remains unclarified, attention should be paid to the constituents of media to be used for testing the pesticidetolerance of microorganisms.

\section{ACKNOWLEDGMENTS}

Financial support by Grants in Aids for Scientific Research (B8-R12-8) from the Ministry of Education, Culture and Science of Japan is gratefully acknowledged.

\section{REFERENCES}

1) S. Kuwatsuka \& M. Igarashi: Soil Sci. Plant Nutr. 21, 405 (1975)

2) I. Watanabe: Soil Sci. Plant Nutr. 19, 109 (1973)

3) I. Watanabe: Jpn. J. Soil Sci. Plant Nutr. 46, 343 (1975) (in Japanese)
4) B. Rott, S. Nitz \& F. Korte: J. Agric. Food Chem. 27, 306 (1979)

5) U. M. Weiss, P. Moza, I. Scheubert, A. Haque \& F. Korte: J. Agric. Food Chem. 30, 1186 (1982)

6) U. M. Weiss, I. Scheubert, W. Klein \& F. Korte: J. Agric. Food Chem. 30, 1191 (1982)

7) H. Kato, K. Sato \& C. Furusaka: J. Pesticide Sci. 6, 43 (1981) (in Japanese)

8) K. Sato: Plant Soil 75, 417 (1983)

9) K. Sato: J. Gen. Appl. Microbiol. 31, 197 (1985)

10) M. Alexander: “Extreme Environments," ed. by M. R. Heinrich, Academic Press, New York, p. 3, 1976

11) K. Izaki, M. Takahashi, Y. Sato, Y. Sasagawa, K. Sato \& C. Furusaka: Agric. Biol. Chem. 45, 765 (1981)

12) S. Matsunaka: "Shokubutsu Dokuri-gaku Nyumon," (Introduction to Plant Toxicology), Tokyo Univ. Press, Tokyo, p. 44, 1976 (in Japanese)

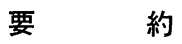

\section{ペンタクロロフェノール $(\mathbf{P C P})$ 灌流土䁃から 分離した細菌群の PCP 耐性}

佐藤 匡

PCP 添加および無添加の灌流土壌から分離し, 分類群 に類別した細菌株の PCP 耐性を, 異なる濃度の PCP を 含んだ培地での生育速度の違いによって評価した。耐性 は, PCP と前培養しても变化しなかったが, 細菌株を分 離した灌流土壌の処理法の相違によって耐性に差がみら れた. すなわち, PCP のみを添加して灌流した土塞から 分離した菌株は，もっとも耐性が強かったが，それにグ リシンが加わると耐性は低下した，水灌流土塞から分離 した菌株は，もっとも耐性が低かった。ささらに，耐性を 細菌の生育速度の違いから評価すると, 細菌の分類群と 耐性との間には密接な関連性があり, 生育速度は細菌種 の PCP 耐性を評価するうえで有効であることが示唆さ れた. その他, 検定培地の組成の差によっても耐性は異 なって現われた。 